\title{
Kadar N-terminal Pro Brain Natriuretic Peptide Anak Penyakit Jantung Bawaan Pirau Kiri ke Kanan pada Sindrom Down
}

\author{
Wardati Rahma, Anindita Soetadji \\ Departemen Ilmu Kesehatan Anak Fakultas Kedokteran Universitas Diponegoro/ RSUP Dr.Kariadi, Semarang
}

\begin{abstract}
Latar belakang. Faktor yang dapat memengaruhi kinerja jantung pada anak dengan sindrom Down kemungkinan dapat memengaruhi kadar hormon N-Terminal Pro Brain Natriuretic Peptide (NT-proBNP) dalam darah. Kadar NT-proBNP lebih tinggi pada anak sindrom Down. Kadar NT-proBNP anak penderita PJB dengan gagal jantung akan sangat tinggi karena berhubungan dengan fungsi ventrikel.

Tujuan. Membuktikan adanya perbedaan kadar NT-proBNP anak penyakit jantung bawaan (PJB) pirau kiri ke kanan bukan sindrom Down dan dengan sindrom Down menurut klasifikasi fungsional.

Metode. Penelitian observasional analitik belah lintang di RSUP Dr. Kariadi. Perhitungan jumlah sampel ditentukan dengan rumus besar sampel untuk uji beda dua kelompok tidak berpasangan. Metode sampling secara konsekutif. Kadar NT-proBNP ditentukan dengan metode ELISA. Uji Mann-Whitney dilakukan untuk menganalisis perbedaan kadar NT-proBNP anak PJB pirau kiri ke kanan bukan sindrom Down dan dengan sindrom Down.

Hasil. Lima puluh subyek yang terdiri atas 25 anak PJB pirau kiri ke kanan bukan sindrom Down dan 25 anak PJB pirau kiri ke kanan dengan sindrom Down dilibatkan dalam penelitian. Tidak terdapat perbedaan kadar NT-proBNP anak PJB pirau kiri ke kanan bukan sindrom Down dan dengan sindrom Down menurut klasifikasi fungsional $(p=0,828)$.

Kesimpulan. Tidak ada perbedaan kadar NT-proBNP antara anak sindrom Down yang menderita PJB pirau kiri ke kanan dengan bukan sindrom Down. Sari Pediatri 2015;17(2):107-12.
\end{abstract}

Kata kunci: gagal jantung, kadar NT, proBNP, PJB pirau kiri ke kanan, sindrom Down

\section{N-terminal Pro Brain Natriuretic Peptide Levels among Children with Congenital Heart Disease with Left to Right Shunt in Down Syndrome}

\author{
Wardati Rahma, Anindita Soetadji
}

\begin{abstract}
Background. There are variations of factors that can influence heart activity in children with congenital heart disease that have left to right shunt among the children of non Down syndrome compared to Down syndrome origin that can influence N-Terminal Pro Brain Natriuretic Peptide (NT-proBNP) levels in serum. NT-proBNP level is usually higher in children with Down syndrome. NT- proBNP level in congenital heart disease (CHD) children with heart failure is usually also very high because of its association with ventricular function.

Objective. To determine the differences of NT-proBNP levels among children with left to right shunt CHD of non Down syndrome compared to Down syndrome origin based upon their functional classifications.

Method. A cross sectional study was performed at Dr. Kariadi hospital. Samples were collected consecutively. Comparison of means for two independent samples test was utilized for samples calculation. NT-proBNP levels were analyzed by ELISA. Mann-Whitney test was used to analyze the differences of NT-proBNP levels between children with left to right shunt CHD of non Down syndrome and Down syndrome origin.

Results. Twenty-five children with left to right shunt CHD children of non Down syndrome and 25 of left to right shunt CHD children with Down syndrome were enrolled into the study. There are no significant differences of NT-proBNP levels between children with left to right shunt CHD non Down syndrome and Down syndrome based on functional classification, with p 0,828.

Conclusion. The NT-proBNP levels between children with left to right shunt CHD of non Down syndrome and Down syndrome origin were not different statistically. Sari Pediatri 2015;17(2):107-12.
\end{abstract}

Keywords: heart failure, NT- proBNP level, left to right shunt CHD, Down syndrome

\footnotetext{
Alamat korespondensi: Dr. Wardati Rahma, Sp.A. RSUD H. Badaruddin. Jl. Jaksa Agung Suprapto, Tanjung, Tabalong, KALSEL, 71513. Telp. +62526-2022651. E-mail : wardatirahma@gmail.com
} 


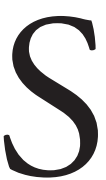
ekitar 40\%-60\% anak dengan sindrom Down memiliki penyakit jantung bawaan. ${ }^{1,2}$ Kelainan jantung bawaan yang dialami anak dengan sindrom Down lebih berat dan mudah diprediksi dibandingkan bukan sindrom Down. ${ }^{3}$ Sampai saat ini, diagnosis gagal jantung pada anak dilakukan secara klinis. Berat ringan gagal jantung atau kemampuan fungsional jantung tersebut secara klinis dinilai berdasarkan kriteria klasifikasi fungsional menurut skoring Ross. ${ }^{4,5}$

Salah satu biomarker gagal jantung adalah NT-proBNP yang merupakan hormon primer dari jantung, disintesis dan dikeluarkan oleh miokardium. ${ }^{6}$ NT-proBNP merupakan fragmen $\mathrm{N}$ terminal yang tidak aktif sehingga NT-proBNP stabil dalam darah. ${ }^{7}$ Peningkatan beban volume dan tekanan menyebabkan ekspresi gen BNP pada keadaan gagal jantung. Keadaan stres hemodinamik jangka panjang mengakibatkan ekspresi gen BNP meningkat secara cepat sebagai respon terhadap stimulus hipertropi sebelum berlanjut menjadi hipertopi. ${ }^{89}$ Beban volume jantung terjadi akibat pirau pada PJB. Beban volume ventrikel jantung akan memicu dikeluarkannya NT-proBNP ke sirkulasi. ${ }^{10}$ Kadar NT-proBNP anak PJB dengan gagal jantung akan sangat tinggi karena berhubungan dengan fungsi ventrikel. ${ }^{6}$ Pemeriksaan kadar NTproBNP dalam darah merupakan salah satu penanda yang berhubungan dengan beratnya gagal jantung. Kadar NT-proBNP berbanding lurus dengan derajat gagal jantung. ${ }^{11}$

Penelitian terdahulu telah menyebutkan bahwa kadar NT-proBNP akan meningkat pada gagal jantung berat. ${ }^{5}$ Pada sindrom Down, gagal jantung terjadi lebih dini. ${ }^{3}$ Pemeriksaan NT-proBNP dilakukan untuk melihat perbedaan antara anak PJB pirau kiri ke kanan bukan sindrom Down dan dengan sindrom Down. Jika kadar NT-proBNP didapatkan jauh lebih tinggi pada kasus sindrom Down, dapat ditentukan bahwa sesak yang terjadi akibat gagal jantung sehingga terapi gagal jantung dapat diberikan. Pada tempat yang tidak memungkinkan dilakukan pemeriksaan ekokardiografi dan sistem rujukan yang sulit, dapat dilakukan pemeriksaan kadar NTpro-BNP untuk membedakan apakah sesak tersebut bagian dari gagal jantung atau kelainan lain yang mirip dengan jantung seperti pneumonia.

Kemungkinan perbedaan kadar NT-proBNP dalam darah dapat memengaruhi kinerja jantung anak dengan sindrom Down dan anak bukan sindrom Down. Berdasarkan latar belakang tersebut , kami berkeinginan untuk meneliti apakah terdapat perbedaan kadar NT-proBNP pada anak PJB pirau kiri ke kanan bukan sindrom Down dan dengan sindrom Down.

\section{Metode}

Subyek penelitian adalah pasien PJB pirau kiri ke kanan usia 1 sampai 120 bulan yang dirawat jalan dan inap di Divisi Kardilogi Anak RSUP Dr. Kariadi, Semarang. Untuk uji beda dua kelompok tidak berpasangan, perhitungan jumlah sampel ditentukan dengan rumus besar sampel. Pengambilan sampel digunakan metode consecutive sampling sampai jumlah sampel terpenuhi. Diagnosis PJB pirau kiri ke kanan terdiri atas DSV, DSA, DAP, dan defek septum atrioventrikular (DSAV) ditentukan berdasarkan hasil ekokardiografi. Ekokardigrafi dilakukan oleh spesialis anak konsultan kardiologi. Klasifikasi gagal jantung ditentukan berdasarkan sistem skoring kriteria gagal jantung menurut Ross dan Reithman yang dimodifikasi. Kriteria anemia ditentukan berdasarkan kadar $\mathrm{Hb}$ $<10,5 \mathrm{mg} \%$.

Frekuensi ISPA adalah frekuensi sakit ISPA selama satu bulan terakhir, ISPA jarang $(<2 \mathrm{x}$ selama satu bulan terakhir) dan ISPA sering ( $\geq 2 \mathrm{x}$ selama satu bulan terakhir). Subjek penelitian dibagi menjadi dua kelompok, yaitu pasien PJB pirau kiri ke kanan bukan sindrom Down dan dengan sindrom Down. Diagnosis sindrom Down ditentukan berdasarkan klinis, meliputi kumpulan gejala klinis yang terdiri atas low set ears dengan overfolded helix, mulut kecil, makroglosia, saddle nose, jari-jari pendek, mata upslanting fissura palpebra, tangan simian crease, jari kaki terdapat jarak/gap antara jari satu dan kedua. Kriteria eksklusi, meliputi gagal ginjal, sepsis, obesitas, dan hipertensi pulmonal.

Analisis data deskriptif dan uji hipotesis. Analisis deskriptif data yang berskala kategorial, seperti jenis kelamin anak, umur, dan sebagainya dinyatakan sebagai distribusi frekuensi dan persentase. Sebaliknya, variabel berskala numerik, seperti kadar NT-proBNP dan sebagainya dinyatakan sebagai rerata dan simpang baku atau median. Analisis perbedaan nilai NT-proBNP menurut klasifikasi fungsional digunakan uji t tidak berpasangan apabila sebaran data normal. Jika sebaran data tidak normal, dilakukan transformasi data. Jika 
variabel baru hasil transformasi terdistribusi normal, dipakai uji t tidak berpasangan, tetapi bila variabel baru hasil transformasi tidak terdistribusi normal, dipilih uji Mann-Whitney. Nilai p dianggap signifikan secara statistik jika kurang dari 0,05 .

\section{Hasil}

Selama periode penelitian didapatkan 50 subyek yang terdiri atas 25 pasien PJB pirau kiri ke kanan bukan sindrom Down dan 25 dengan sindrom Down. Berdasarkan karakteristik subyek penelitian, peneliti ingin menunjukkan apakah data dari dua kelompok yang diteliti homogen. Usia dan kadar $\mathrm{Hb}$ tidak homogen. Jika tidak didapat perbedaan (homogen), tidak akan memengaruhi hasil. Sebaliknya, jika tidak homogen, akan memengaruhi hasil. Variabel yang memengaruhi hasil seperti kadar $\mathrm{Hb}$ akan dianalisis lebih lanjut. Karakteristik subyek penelitian tertera pada Tabel 1.

Subyek penelitian pada kelompok PJB pirau kiri ke kanan bukan sindrom Down dan dengan sindrom
Down yang dikategorikan tidak anemia dianalisis menggunakan uji beda. Terdapat 22 subyek pada kelompok PJB pirau kiri ke kanan bukan sindrom Down yang tidak anemia dan 18 PJB pirau kiri ke kanan dengan sindrom Down yang tidak anemia. Hasil penelitian menunjukkan bahwa tidak didapatkan perbedaan antara kadar NT-proBNP anak PJB pirau kiri ke kanan bukan sindrom Down dan dengan sindrom Down menurut klasifikasi fungsional $(\mathrm{p}=0,828)$. Hasil uji beda dari kadar NT-proBNP anak PJB pirau kiri ke kanan bukan sindrom Down dan dengan sindrom Down menurut klasifikasi fungsional tertera pada Tabel 2. Perbedaan kadar NT-proBNP menurut klasifikasi fungsional gagal jantung pada anak kasus PJB pirau kiri ke kanan bukan sindrom Down dan dengan sindrom Down (Tabel 2).

Secara statistik tidak terdapat perbedaan kadar NT-proBNP antara anak PJB pirau kiri ke kanan bukan sindrom Down dan dengan sindrom Down. Namun, pada kelompok gagal jantung sedang sampai berat dijumpai selisih kadar NT-proBNP yang secara klinis cukup besar meskipun secara statistik tidak bermakna.

Tabel 1. Karakteristik subyek penelitian $(\mathrm{n}=50)$

\begin{tabular}{|c|c|c|c|}
\hline Karakteristik & $\begin{array}{l}\text { Bukan sindrom Down } \\
(\mathrm{n}=25)\end{array}$ & $\begin{array}{l}\text { Sindrom Down } \\
(n=25)\end{array}$ & $\mathrm{p}$ \\
\hline Usia (bulan) & $42(12-121)$ & $9(2-84)$ & $0,0001^{*}$ \\
\hline \multicolumn{4}{|l|}{ Jenis kelamin (\%) } \\
\hline Laki-laki & $10(40)$ & $9(36)$ & \multirow[t]{2}{*}{$0,771^{* *}$} \\
\hline Perempuan & $15(60)$ & $16(64)$ & \\
\hline \multicolumn{4}{|l|}{ PJB $(\%)$} \\
\hline DSV & $12(48)$ & $5(20)$ & \\
\hline DSA & $4(16)$ & $6(24)$ & \\
\hline DAP & $5(20)$ & $6(24)$ & \\
\hline DSAV & $4(16)$ & $6(24)$ & \\
\hline DAP \& DSA & $0(0)$ & $2(8)$ & \\
\hline \multicolumn{4}{|l|}{ Anemia } \\
\hline Kadar $\mathrm{Hb}$ & $11,9(10,2-14,6)$ & $10,9(9,5-12,3)$ & $0,0001^{*}$ \\
\hline \multicolumn{4}{|l|}{ Frekuensi ISPA (\%) } \\
\hline Jarang & $18(72)$ & $16(64)$ & \multirow[t]{2}{*}{$0,544^{* *}$} \\
\hline Sering & $7(28)$ & $9(36)$ & \\
\hline \multicolumn{4}{|l|}{ Skor klasifikasi fungsional gagal jantung } \\
\hline Klasifikasi fungsional gagal jantung & $4(2-8)$ & $6(1-11)$ & \multirow[t]{3}{*}{$0,87^{*}$} \\
\hline Tanpa gagal jantung & $3(12)$ & $3(12)$ & \\
\hline Ringan & $17(68)$ & $12(48)$ & \\
\hline Sedang-berat & $5(20)$ & $10(40)$ & $0,093^{*}$ \\
\hline
\end{tabular}

*Uji Mann-Whitney; DSV: defek septum ventrikel; DSAV: defek septum atrioventrikularis

**Uji Chi square; DSA: defek septum atrium; DAP: duktus arteriosus persisten; ISPA: infeksi saluran pernapasan akut 
Tabel 2. Perbedaan kadar NT-proBNP menurut klasifikasi fungsional dan gagal jantung

\begin{tabular}{|c|c|c|c|c|c|}
\hline Kadar NT-proBNP & $\mathrm{n}$ & Bukan sindrom Down & $\mathrm{n}$ & Sindrom Down & $\mathrm{p}$ \\
\hline Kadar NT-proBNP, median (rentang) & 22 & $\begin{array}{c}337,61 \\
(33,86-2612,30)\end{array}$ & 18 & $\begin{array}{c}305,29 \\
(32,22-1497,20)\end{array}$ & $0,828^{*}$ \\
\hline $\begin{array}{l}\text { Gagal jantung } \\
\text { Tanpa gagal jantung } \\
\text { (skor 0-2) }\end{array}$ & 3 & $\begin{array}{c}46,75 \\
(32,2-141,02)\end{array}$ & 3 & $\begin{array}{c}68,40 \\
(32,22-72,30)\end{array}$ & $0,827^{*}$ \\
\hline $\begin{array}{l}\text { Gagal jantung ringan } \\
\text { (skor 3-6) } \\
\text { Gagal jantung sedang-berat } \\
(\text { skor }>7)\end{array}$ & 17 & $\begin{array}{c}141,02 \\
(33,86-261,30) \\
691,19 \\
(522,58-1431,80)\end{array}$ & 12 & $\begin{array}{c}337,15 \\
(122,62-2394,50) \\
1083,62 \\
(248,63-3000,00)\end{array}$ & $0,144^{*}$ \\
\hline
\end{tabular}

*Uji Mann Whitney

\section{Pembahasan}

Jenis kelamin antara kelompok pasien PJB pirau kiri ke kanan bukan sindrom Down dan dengan sindrom Down tidak didapatkan perbedaan. Penelitian Freeman $\mathrm{dkk}^{13}$ menyatakan bahwa penderita sindrom Down dengan jenis kelamin perempuan dua kali lipat lebih besar berpeluang mengalami anomali jantung. Etnis kulit kulit hitam juga dua kali lipat menderita anomali jantung dibanding kulit putih. Namun, berdasarkan penelitian Torfs $\mathrm{dkk}^{14}$ tidak didapatkan perbedaan jenis kelamin dan etnis. Penelitian Miyague $\mathrm{dkk}^{15}$ menunjukkan bahwa tidak terdapat perbedaan jenis kelamin pada anak penderita PJB.

Terdapat perbedaan antara usia kelompok PJB pirau kiri ke kanan bukan sindrom Down dan dengan sindrom Down. Kelompok PJB pirau kiri ke kanan dengan sindrom Down relatif lebih muda, yaitu ratarata 9 bulan dengan rentang usia antara 2-84 bulan. Karena tingginya insiden PJB pada sindrom Down, American Academy of Pediatric merekomendasikan agar melakukan ekokardiografi pada semua bayi yang baru lahir dengan sindrom Down. ${ }^{16}$ Anak dengan sindrom Down sering kali datang ke pelayanan kesehatan karena penyakit di luar jantung sehingga, secara tidak sengaja, kelainan jantung terdeteksi saat kunjungan. ${ }^{13}$

Distribusi subyek penelitian menurut klasifikasi fungsional gagal jantung menunjukkan $12 \%$ dari setiap kelompok PJB pirau kiri ke kanan bukan sindrom Down dan dengan sindrom Down dikategorikan tanpa gagal jantung. Sebagian besar mengalami gagal jantung ringan dan sedang sampai berat.

Pemantauaan terhadap resistensi vaskular paru pada kasus PJB (DSV, DSAV, dan TF) dengan sindrom Down menunjukkan bahwa resistensi vaskular paru mencapai level patologis pada $88 \%$ kasus. Perbaikan luaran hanya terjadi pada sebagian kecil kasus. Resistensi vaskular bervariasi pada tahap awal perkembangan penyakit vaskular obstruktif paru pada sindrom Down. ${ }^{17}$ Kadar NT-proBNP mengalami peningkatan pada pasien hipertensi pulmonal primer dan sekunder yang berat. ${ }^{18}$ Gan dkk $^{19}$ melakukan penelitian pada pasien hipertensi pulmonal usia 2180 tahun. Sampel penelitan adalah 15 pasien yang baru didiagnosis sebagai hipertensi pulmonal dan 15 dengan hipertensi pulmonal dalam terapi. Hasil penelitian tersebut menunjukkan bahwa kadar NTproBNP berhubungan dengan tekanan atrium kanan, saturasi vena mixing dan indeks kardiak, tetapi tidak berhubungan dengan tekanan arteri pulmonalis atau indeks resistensi vaskular paru. Walaupun pasien sindrom Down dengan PJB memiliki peluang lebih besar untuk mengalami hipertensi arteri pulmonalis yang tidak reversibel. Namun, kondisi hemodinamik hipertensi pulmonal dan setelah dilakukan oxygent test tidak menunjukkan perbedaan dengan kelompok PJB bukan sindrom Down. ${ }^{20}$

Berdasarkan teori, kadar NT-proBNP lebih tinggi pada kasus sindrom Down dengan gagal jantung. ${ }^{20}$ Hasil penelitian kami tidak mendapatkan perbedaan kadar NT-proBNP pada anak PJB pirau kiri ke kanan bukan sindrom Down dan dengan sindrom Down. Penyebab yang mungkin dari hasil tersebut karena pasien PJB dengan sindrom Down kemungkinan telah mendapatkan terapi medikamentosa dan ketaatan minum obat tergolong baik sehingga respon terapi baik. Penelitian Troughton $\mathrm{dkk}^{12}$ menunjukkan bahwa terjadi penurunan kadar BNP pada kasus gagal jantung setelah mendapat terapi diuretik, vasodilator, ACE inhibitor, ARB, 
penghambat beta, dan antagonis aldosteron. Selain itu, pada kasus sindrom Down sering terjadi gejala yang rancu, apakah gejala tersebut karena gagal jantung atau karena sindrom Down. Pasien sindrom Down dengan skor gagal jantung tinggi belum tentu menderita gagal jantung derajat berat. Sebagai contoh, takipneu dan dispneu dapat terjadi karena penyakit paru, takikardi dapat terjadi karena kecemasan atau anemia, hepatomegali dapat terjadi pada penyakit infeksi sistemik. Kondisi tersebut akan menyebabkan penilaian skor gagal jantung menjadi tinggi dan gagal jantung dianggap berat. Meskipun pada kenyataannya, keadaan tersebut bukan karena gagal jantung sehingga kadar NT-proBNP pada PJB pirau kiri ke kanan dengan sindrom Down tidak setinggi yang diprediksi.

Keadaan lain yang dapat memengaruhi kadar NTproBNP adalah rentang usia subyek pada kelompok bukan sindrom Down yang lebar sementara kadar NT-proBNP dapat bervariasi menurut usia. ${ }^{21}$ Penilaian skor gagal jantung bisa saja keliru karena dilakukan oleh pemeriksa yang berbeda-beda.

\section{Kesimpulan}

Kadar NT-proBNP dapat digunakan sebagai penanda beratnya gagal jantung walaupun tidak terdapat perbedaan kadar NT-proBNP anak PJB pirau kiri ke kanan bukan sindrom Down dan dengan sindrom Down menurut klasifikasi fungsional. Kadar NTproBNP yang tinggi pada kasus PJB pirau kiri ke kanan merupakan penanda derajat gagal jantung yang berat. Namun, klinis gagal jantung yang tampak berat belum tentu disertai dengan kadar NT-proBNP yang tinggi karena terdapat faktor di luar jatung yang dapat membuat klinis gagal jantung tampak lebih berat dari pada kondisi sebenarnya.

\section{Daftar pustaka}

1. Rebecca S. Primary Care of Infants and Young Children with Down Syndrome. Diakses pada 12 Januari 2012. Didapat dari: http:/www.aafp.afp/990115ap/381.html.

2. Bittles A, Bower C, Hussain R, Glasson E. The four ages af Down syndrome. Eur J Pub Health 2006;17:221-5.

3. Cohen M, Mansoor D, Langut M, Lorber A. The heart. Dalam: Selikowitz M, penyunting. Down syndrome the fact. Edisi ke-2. Great Britain: Oxford University Press;2002.h.83-90.

4. Sukardi R. Penatalaksanaan terkini gagal jantung pada anak. Dalam: Putra ST, Djer MM, Roeslani $\mathrm{RD}$, Endyarni B, Yuniar I, penyunting. Management of pediatric heart disease for practitioners: from early detection to intervention. Jakarta: Departemen IKA FKUI-RSCM; 2009.h.40-63.

5. Mott A, Breinholt J. Classification of types of heart failure. Dalam: Chang A TJ, penyunting. Heart failure in children and young adults from molecular mechanism to medical and surgical strategies. Philadelphia: Saunders Elsevier;2006.h.211-7.

6. Rumayor A, Januzzi J. Use of natriuretic peptides in diagnosis of heart failure. Dalam: Lemos J, penyunting. Biomarkers in heart disease. Dallas: American Heart Association; 2008.h.95-115.

7. Koch A, Zink S, Singer H. B-type natriuretic peptide in paediatric patients with congenital heart disease. Eur Heart J 2006;27:861-6.

8. Maisel A. Rapid Measurements of B-type natriuretic peptide in the emergency diagnosis of heart failure. $\mathrm{N}$ Engl J Med 2002;3:161-7.

9. Driscoll DJ. Principles of inheritance and genetics of congenital heart disease. Fundamental of pediatric cardiology: Lippincott Williamn \& Wilkins; 2006.h. 62-9.

10. Buchhorn R. Neurohormonal and immunologic Aspects of Pediatric Heart Failure. Dalam: Shaddy R, Wernovsky G, penyunting. Pediatric Heart Failure. New York: Taylor \& Francis Group; 2005.h.105-36.

11. Eerola A, Jokinen E, Boldt T, Mattila IP, Pihkala JI. Serum levels of natriuretic peptides in children before and after treatment for an atrial septal defect, a patent ductus arteriosus, and a coarctation of the aorta-a prospective study. Int J Pediatr 2010:22;1-9.

12. Troughton RW, Frampton CM, Yandle TG, Espiner EA, Nicholls MG, Richards AM. Treatment of heart failure guided by plasma aminoterminal brain natriuretic peptide (N-BNP) concentrations. Lancet 2000;355:1126-30.

13. Freeman SB, Bean LH, Allen EG, Tinker SW, Locke AE, Druschel C, dkk. Ethnicity, sex, and the incidence of congenital heart defects: a report from the National Down Syndrome Project. Gene Med 2008;10:173-81.

14. Torfs CP, Christianson RE. Anomalies in Down syndrome individuals in a large population-based registry. Am J Med Genet 1998;77:431-8.

15. Miyague NI, Cardoso SM, Meyer F, Ultramari FT, Araújo FH, Rozkowisk I, dkk. Epidemiological study 
of congenital heart defects in children and adolescents. Arq Bras Cardiol 2003;80:274-8.

16. Hsu DT, Pearson GD. Heart failure in children: part I: history, etiology, and pathophysiology. Circ Heart Fail 2009;2:63-70.

17. Thieren M, Stijns-Cailteux M, Trémouroux-Wattiez M, Jaumin P, Kestens-Servaye Y, Moulin D, dkk. Congenital heart diseases and obstructive pulmonary vascular diseases in Down's syndrome. Apropos of 142 children with trisomy 21. Arch Mal Coeur Vaiss 1988;81:655-61.

18. Aliyu YZ, Suleiman A, Attah E, Mam AI, Babadoko A, Nouraie M, dkk. NT-pro BNP as a marker of cardiopulmonary status in sickle cell anemia in africa. Br J Haematol 2010;150:102-7.

19. Gan CT. NT-proBNP reflects right ventricular structure and function in pulmonary hypertension. Eur Respir J 2006;28:1190-4.

20. Vázquez-Antona CA, Lomelí C, Buendía A, VargasBarrón J. Pulmonary hypertension in children with Down's syndrome and congenital heart disease. Is it really more severe? Arch Cardiol 2006;76:16-27.

21. Nir A. NT-pro-B-type natriuretic peptide in infants and children: reference value based on combined data from four studies. Pediart Cardiol 2009;30:3-8. 